\title{
Sifat Fisik, Kandungan Fitokimia dan Aktivitas Antibakteri Minyak Essensial Kulit Batang Akway (Drimys piperita Hook f.)
}

\author{
The Physical Properties, Phytochemicals Content and Antibacterial Activity of Essential Oil \\ of Akway (Drimys piperita hook F) Stem Barks
}

\author{
${ }^{1}$ Muhammad Zakariyah, ${ }^{* 2}$ Gino Nemesio Cepeda, ${ }^{2}$ Hostalige Hutasoit \\ ${ }^{1}$ Alumni Jurusan Teknologi Pertanian, Universitas Papua \\ ${ }^{2}$ Jurusan Teknologi Pertanian, Universitas Papua \\ Jl. Gunung Salju Amban, Manokwari 98314. \\ *Email: ginocepeda.gc@gmail.com
}

\begin{abstract}
Essential oil is the liquid products obtained by extraction process from various part of aromatic plants. Akway (Drimys piperita Hookf.) is an aromatic plant which has stem barks contained essential oils. The concentrations and types of essential oil compounds highly affected its physicochemical and antibacterial properties. The objectives of the research were to determine physical properties, phytochemical contents and antibacterial potency of essential oil extracted from akway stem bark. Extraction process were done by using hydrodistillation method. Determination of phyical properties were performed to colour, solubility in alcohol $80 \%$ and refractive index while phytochemical contents were done qualitatively to terpenoids, flavonoids, alkaloids and saponins. Antibacterial activity assays were done using agar disc diffusion method on essential oil concentration of 0-10\%. The results indicated that physical properties of akway stem barks essensial oil : light yellowish colour, solubility in alcohol 80\% was 1:2, and refractive index 1.4942. The essential oil contained terpenoids, flavonoids, alkaloids and saponins also could inhibited growth of pathogenic bacteria at minimum inhibition concentration $2.7-5.0 \mathrm{mg} / \mathrm{ml}$.
\end{abstract}

Keywords: Physical properties, phytochemical, essential oil, akway.

\begin{abstract}
Abstrak
Minyak essensial merupakan produk cairan yang diperoleh melalui proses ekstraksi dari berbagai bagian tumbuhan aromatik. Akway (Drimys piperita Hook f.) merupakan salah satu jenis tumbuhan aromatik yang memiliki kulit batang yang mengandung minyak essensial. Konsentrasi dan jenis senyawa penyusun minyak essensial sangat menentukan sifat fisik, kimia dan antibakterinya. Penelitian ini bertujuan untuk menentukan sifat fisik dan kandungan fitokimia minyak essensial kulit batang akway serta potensi antibakterinya terhadap pertumbuhan bakteri patogen. Proses ekstraksi minyak essensial kulit batang akway dilakukan menggunakan metode distilasi air. Pengujian sifat fisik yang dilakukan meliputi warna, kelarutan dalam alkohol dan indeks refraktif sedangkan pengujian kandungan kualitatif fitokimianya meliputi terpenoid, flavonoid, alkaloid dan saponin. Pengujian aktivitas antibakteri dilakukan pada konsentrasi $0-10 \%$ dengan metode difusi cakram di dalam medium agar. Hasil menunjukkan bahwa minyak essensial kulit batang akway memiliki warna jernih kekuningan, kelarutan $1: 2$ dalam alkohol 80\%, dan indeks refraktif sebesar 1,4942. Minyak essensial kulit batang akway mengandung terpenoid, flavonoid, alkaloid dan saponin serta dapat menghambat pertumbuhan bakteri patogen dengan konsentrasi hambat tumbuh minimum sebesar 2,7-5,0 mg/ml.
\end{abstract}

Kata kunci: sifat fisik, fitokimia, antibakteri, minyak essensial, akway. 


\section{PENDAHULUAN}

Minyak essensial merupakan produk cairan yang mengandung senyawa-senyawa aromatik dan volatil yang diisolasi dari berbagai bagian tumbuhan. Minyak ini umumnya diperoleh dari satu atau lebih bagian tumbuhan aromatik seperti bunga, daun, batang, kulit kayu, kayu, akar, biji, buah dan rizoma (Badasa dkk., 2014). Minyak essensial dan komponen aktifnya memiliki aktivitas antivirus, antibakteri, antijamur, antitoksigenik dan sifat insektisida (Perricone dkk., 2015).

Minyak essensial hasil distilasi dari beberapa bagian tumbuhan aromatik dilaporkan memiliki aktivitas antibakteri yang kuat. Minyak essensial daun Zataria multiflora, rimpang Zingiber officinale dan kulit batang Cinnamomum zeylanicum bersifat menghambat pertumbuhan bakteri Staphyloccocus aureus dan Escherichia coli di dalam medium agar (Amin dkk., 2010; Lopez dkk., 2017; Al-fekaiki dkk., 2017).

Akway (Drimys piperita Hook f.) merupakan salah satu jenis tumbuhan aromatik yang termasuk dalam kelompok tumbuhan berkayu, berdaun hijau sepanjang tahun dan memiliki kulit batang yang berwarna merah kecoklatan dengan aroma dan rasa yang pedas. Sebagai tumbuhan aromatik, bagian kulit batang dan daun akway mengandung senyawasenyawa volatil dalam bentuk minyak essensial. Daun akway mengandung minyak essensial sebesar 0,20\% sedangkan kandungan minyak atsiri pada bagian kulit batang sebesar $0,37 \%$ dan tersusun dari senyawa $\alpha$-pinen, $\beta$ pinen dan 4-terpineol masing-masing dengan konsentrasi $20,24 \%, 14,88 \%$ dan $13,16 \%$ (Cepeda dkk., 2011a; Cepeda dkk., 2011b).

Senyawa penyusun utama dalam minyak essensial dapat mencapai $85 \%$ sedangkan senyawa lainnya berada dalam konsentrasi yang sangat rendah. Berdasarkan struktur kimia, senyawa aktif penyusun minyak essensial dapat dibagi kedalam beberapa kelompok yaitu alkohol, fenol, aldehida, keton, hidrokarbon dan eter (Cabarkapa dkk., 2016). Konsentrasi dan jenis senyawa penyusun minyak essensial tersebut sangat bervariasi antar species (Turek Stintzing, 2013; Butnariu dan Sarac, 2018).

Konsentrasi dan jenis senyawa penyusun minyak essensial sangat menentukan sifat fisik dan kimia serta sifat antibakterinya. Sampai saat ini, informasi sifat fisik dan kimia serta antibakteri minyak essensial kulit batang akway masih terbatas. Oleh sebab itu penelitian ini bertujuan untuk mengetahui sifat fisik dan kandungan fitokimia serta potensi aktivitas antibakteri minyak essensial kulit batang akway terhadap pertumbuhan bakteri patogen dalam medium sintetik.

\section{METODOLOGI}

\section{Bahan dan alat}

Bahan-bahan yang digunakan dalam penelitian ini meliputi: (a) bahan untuk preparasi dan proses penyulingan bubuk kulit batang akway, yaitu batang akway dan air bersih, (b) bahan untuk analisis fisikokimia, yaitu alkohol 80\%, terpentin, kloroform, anhidrida asetat, asam sulfat dan reagen Dragendorf, dan (c) Bahan-bahan yang digunakan untuk analisis antibakteri yang meliputi isolat bakteri Escherichia coli, Bacillus cereus, Pseudomonas aeruginosa dan Staphylococcus aureus yang diperoleh dari Laboratorium Biokimia PAU IPB, nutrient broth (NB) dan nutrient agar (NA) diperoleh dari oxoid, sodium klorida Merck dan etanol absolut dari JT Baker.

Peralatan yang digunakan dalam penelitian ini adalah: (a) peralatan untuk preparasi bubuk kulit batang akway dan distilasi minyak atsiri meliputi parang, pisau, hammer mill dan peralatan distilasi, (b) peralatan untuk analisis fisikokimia, yang meliputi refractometer, Thin Layer Chromatography plate, pipet dan peralatan gelas dan, (c) peralatan pengujian aktivitas antibakteri meliputi cawan petri, laminar air flow (LAF), hot plate, inkubator, mikropipettor, vorteks, caliper dan peralatan gelas lainnya.

\section{Metode Penelitian}

Penelitian ini menggunakan metode eksperimen dalam rancangan acak kelompok. Perlakuan yang digunakan adalah perlakuan konsentrasi ekstrak yang terdiri dari konsentrasi ekstrak $0,2,4,6,8$ dan $10 \%$. Setiap perlakuan diujikan pada 4 kelompok bakteri, yaitu E. coli, B. cereus, $P$. aeruginosa dan S. aureus.

\section{Persiapan bubuk kulit batang akway}

Batang kayu akway yang digunakan dalam penelitian ini adalah batang dengan diameter 8-10 $\mathrm{cm}$ yang diperoleh dari 
Kampung Sururey, Distrik Anggi, Kabupaten Pegunungan Arfak dibersihkan dengan air mengalir untuk menghilangkan kotoran yang menempel pada permukaan batang. Selanjutnya kulit batang dipisahkan menggunakan pisau. Kulit batang yang diperoleh dikering-anginkan dalam ruangan menggunakan air conditioner sampai kering dan rapuh dengan kadar air $10-12 \%$. Kulit batang kering digiling menggunakan hammer mill dengan ukuran 40 mesh. Bubuk kulit batang dikemas dalam kemasan plastik.

\section{Proses distilasi bubuk kulit batang}

Proses distilasi minyak essensial kulit batang akway dilakukan dengan metode hydrodistillation (Rassem dkk., 2016). Sebanyak $300 \mathrm{~g}$ bubuk kulit batang akway dimasukkan dalam labu distilasi $2000 \mathrm{ml}$ dan ditambahkan air sebanyak $900 \mathrm{ml}$, kemudian dihubungkan dengan kondensor pada alat disitilasi. Bagian ujung kondensor lainnya dihubungkan dengan penampung distilat. Kondensor dialiri dengan air mengalir dengan menggunakan pompa. Campuran bubuk kulit batang akway dan air di dalam labu distilasi dipanaskan menggunakan hot plate sampai distilat yang menetes dari kondensor mengandung minyak essensial. Distilat yang diperoleh dipisahkan minyak essensialnya dari air menggunakan labu pemisah minyak dan air.

\section{Rendemen}

Penentuan rendemen minyak essensial kulit batang akway dilakukan dengan menggunakan formula sebagai berikut :

Rendemen minyak essensial $=$

Vol. minyak essensial hasil distilasi (ml)

Berat bubuk kulit batang akway (g)

\section{Warna}

Penentuan warna minyak essensial kulit batang akway dilakukan secara visual. Warna ditentukan berdasarkan penampakan fisik minyak essensial (Shabbir dkk., 2009).

\section{Kelarutan}

Pengujian kelarutan minyak essensial di dalam pelarut organik etanol $80 \%$ dilakukan secara manual (Majumder dkk., 2014). Pipet 1 $\mathrm{ml}$ etanol ke dalam gelas piala $10 \mathrm{ml}$, kemudian teteskan minyak essensial menggunakan pipet tetes. Setiap penambahan satu tetes minyak essensial kocok dan amati kelarutannya. Jika minyak essnsial larut sempurna tambahkan satu tetes berikutnya kocok dan amati kelarutannya. Prosedur ini dilakukan sampai minyak essensial tidak larut. Jumlah volume minyak essensial yang larut sempurna dalam etanol $80 \%$ merupakan kelarutan minyak essensial.

\section{Indeks bias}

Pengujian indeks refraktif minyak essensial kulit batang akway dilakukan menggunakan refraktometer Abbe pada suhu $25^{\circ} \mathrm{C}$ (Barkatullah dkk., 2012). Dua tetes minyak essensial akway ditetesi pada permukaan prisma refraktometer, kemudian prisma ditutup erat dengan memutar sekrup untuk mengencangkan tutup prisma. Refraktometer didiamkan selama 5 menut. Setelah itu dilakukan pembacaan indeks refraktif pada layar refraktometer.

\section{Senyawa golongan terpenoid}

Pengujian kandungan senyawa golongan terpenoid dilakukan dengan prosedur sebagai berikut: Sebanyak $1 \mathrm{ml}$ minyak essensial dilarutkan kedalam kloroform. Kemudian larutan ditambahkan 10 tetes asam anhidrida asetat dan 3 tetes asam sulfat pekat. Larutan diaduk perlahan-lahan dan dibiarkan beberapa menit. Hasil positif ditandai dengan terbentuknya warna merah atau ungu (Harbone, 1996).

\section{Senyawa golongan saponin}

Pengujian kandungan saponin dalam minyak essensial menggunakan metode foam test (Tiwari dkk., 2011). Sebanyak $1 \mathrm{ml}$ minyak essensial di dalam tabung reaksi ditambahkan $10 \mathrm{ml}$ air panas kemudian campuran didinginkan. Selanjutnya campuran diaduk selama 10 menit. Hasil positif ditandai dengan terbentuknya buih yang bertahan sampai 10 menit.

\section{Senyawa golongan alkaloid}

Pengujian kandungan senyawa golongan alkaloid di dalam minyak essensial dilakukan dengan menggunakan metode uji Dragendorf f (Tiwari dkk., 2011). Sampel minyak essensial sebanyak 3 tetes ditambahkan dengan 3 tetes pereaksi Dragendorff. Hasil positif terdapatnya senyawa golongan alkaloid ditandai dengan terbentuknya endapan merah. 


\section{Senyawa golongan flavonoid}

Pengujian kandungan senyawa golongan flavonoid di dalam minyak essensial dilakukan dengan prosedur sebagai berikut: Sebanyak $1 \mathrm{ml}$ minyak essensial ditambahkan beberapa tetes asam sulfat pekat. Hasil uji positif ditandai dengan terbentuknya warna kuning untuk senyawa flavon dan flavonol, warna jingga atau krem untuk senyawa flavonoid dan warna merah tua atau krem untuk senyawa kalkon (Harbone, 1996).

\section{Persiapan kultur bakteri}

Vial isolat bakteri dibuka secara aseptik di dalam LAF dan ditambahkan dengan $1 \mathrm{ml}$ medium NB. Campuran tersebut diaduk menggunakan vorteks sampai tercampur sempurna. Campuran tersebut dipipet dan dimasukkan ke dalam tabung reaksi yang berisi $10 \mathrm{ml}$ NB steril. Kultur kemudian dimasukkan dalam inkubator dengan suhu $37^{\circ} \mathrm{C}$ dan diinkubasi selama 24 jam. Kultur yang tumbuh dalam medium NB, diinokulasi pada permukaan agar miring NA. Kultur dalam medium agar miring siap digunakan dalam pengujian.

\section{Aktivitas antibakteri}

Pangujian aktivitas antibakteri dilakukan dengan menggunakan metode agar disc diffusion (Seow dkk., 2014 ). Sebanyak 15 $\mathrm{ml}$ medium NA steril dituang ke dalam cawan petri steril hingga ketebalan $\pm 4 \mathrm{~mm}$. Setelah medium membeku, disimpan di dalam inkubator suhu $40^{\circ} \mathrm{C}$ selama $1-2$ hari sampai tidak terlihat uap air pada cawan petri. Pada permukaan medium agar dalam cawan petri dituang $100 \mu 1$ kultur bakteri uji (jumlah sel $1 \mathrm{x}$ $10^{5} \mathrm{CFU} / \mathrm{ml}$ ) yang berasal dari kultur medium NB. Kultur pada permukaan medium NA dalam cawan petri disebarkan merata dipermukaan medium dengan menggunakan pipa gelas berbentuk L. Kertas saring dengan diameter $6 \mathrm{~mm}$ (cakram) ditetesi dengan $15 \mu \mathrm{l}$ larutan minyak essensial dalam alkohol sesuai dengan perlakuan $(0,2,4,6,8$ dan 10\%). Cawan petri diinkubasi pada suhu $37^{\circ} \mathrm{C}$ selama 24 jam. Aktivitas antibakteri minyak essensial diukur berdasarkan zona bening yang terbentuk di sekeliling cakram menggunakan caliper.

\section{Konsentrasi hambat tumbuh minimum (KHTM)}

Penentuan nilai KHTM dilakukan menggunakan metode difusi agar (Bloomfield, 1991). Nilai KHTM minyak essensial akway ditentukan melalui analisis regresi linear antara ln konsentrasi minyak essensial (ln Kme) pada sumbu $\mathrm{X}$ dan kuadrat diameter zona penghambatan minyak atsiri pada beberapa konsentrasi $\left(\mathrm{DZP}^{2}\right)$ pada sumbu Y. Perpotongan antara persamaan regresi linear $\mathrm{Y}=\mathrm{a}+\mathrm{bX}$ dengan sumbu $\mathrm{X}$ adalah nilai $\ln$ Kme pada $\mathrm{Y}=0$ (Kme0). Nilai KHTM adalah $0.25 \mathrm{x} \mathrm{e}^{\mathrm{Kms} 0}$.

\section{Analisis data}

Data yang diperoleh dari hasil pengujian dianalisis secara tabulasi. Data hasil analisis ditampilkan dalam bentuk tabel dan grafik.

\section{HASIL DAN PEMBAHASAN}

\section{Rendemen minyak essensial}

Penentuan rendemen minyak essensial kulit batang akway bertujuan untuk mengetahui kandungan minyak essensial yang dapat diekstrak dengan metode distilasi air. Hasil menunjukkan bahwa kandungan minyak essensial kulit batang akway sebesar 0,37\% .

Kandungan minyak essensial kulit batang akway relatif lebih rendah dibandingkan kandungan minyak essensial kulit batang Cinnamomum zeylanicum, Cinnamomum altissimum dan ranting akway D. angustifolia yang masing-masing sebesar 5\%, 1,9\% dan 0,47\% (Al-fekaiki dkk., 2017; Abdelwahab dkk., 2017; Santos dkk., 2013). Namun demikian kandungan minyak essensial kulit batang akway masih lebih tinggi dibandingkan dengan minyak essensial kulit batang Schefflera quangtriensis, daun cinammomum burmanii, rimpang Alpinia purpurata dan Zingiber officinale yang masing-masing sebesar $0,02 \%, 0,1 \%, 0,24$ dan 0,06 (Huong dkk., 2018; Nugraheni dkk., 2016; Rialita dkk., 2015).

Kandungan minyak essensial yang bervariasi antar tumbuhan satu dengan lain disebabkan pengaruh lingkungan dan faktor genetik tumbuhan. Menurut Duarte dkk., (2013), kandungan minyak essensial dalam tumbuhan bergantung pada faktor genetik dan lingkungan. 


\section{Sifat fisik}

Pengujian sifat fisik minyak essensial kulit batang akway meliputi warna, kelarutan dalam alkohol dan indeks refraktif. Hasil menunjukkan bawah minyak essensial kulit batang akway memiliki warna jernih kekuningan, kelarutan $1: 2$ dalam alkohol $80 \%$ dan indeks refraktif sebesar 1,4942 (Tabel 1.). Tabel 1. Sifat fisik minyak essensial kulit

\begin{tabular}{lc}
\multicolumn{2}{c}{ batang akway } \\
\hline \multicolumn{1}{c}{ Sifat Fisik } & $\begin{array}{c}\text { Hasil } \\
\text { Pengamatan }\end{array}$ \\
\hline Warna & $\begin{array}{c}\text { Jernih } \\
\text { kekuningan } \\
\text { Indeks refraktif pada } 25^{\circ} \mathrm{C}\end{array}$ \\
$\begin{array}{l}\text { Kelarutan dalam alkohol } \\
80 \%\end{array}$ & $1: 2942$ \\
\hline
\end{tabular}

Warna minyak essensial kulit batang akway relatif berbeda dengan minyak essensial dari sumber tumbuhan lainnya. Minyak essensial daun Myristica fragrans, Cupressus benthamii dan Lantana camara berwarna kuning pucat (Damayanti dkk., 2015; Wibowo dan Komarayati, 2015; Badasa dkk., 2014). Minyak essensial tangkai bunga Rosa centifolia berwarna coklat kekuningan (Shabbir dkk., 2009) sedangkan minyak essensial rimpang Alpinia purpurata berwarna kuning kecoklatan (Rialita dkk., 2015).

Indeks refraktif merupakan salah satu sifat fisik yang menentukan mutu minyak essensial. Indeks refraktif merupakan perbandingan antara kecepatan cahaya di dalam ruang kosong (vakum) dan kecepatan cahaya di dalam medium (Koohyar, 2013). Indeks refraktif minyak essensial kulit batang akway relatif sama dengan indeks refraktif minyak essensial Lantana camara, biji pala, rimpang Alpinia purpurata dan daun Cinammomum burmanii yang masing-masing sebesar 1,488, 1,498, 1,480 dan 1,481 (Badasa dkk., 2014; Marzuki dkk., 2014; Rialita dkk., 2015; Nugraheni dkk., 2016). Indeks refraktif digunakan untuk menentukan kemurnian dan mutu minyak essensial (Ospina dkk., 2016).

Sifat fisik kelarutan minyak essensial dalam alkohol ditentukan oleh sifat komponen penyusunnya terutama senyawa terpen dan turunannya (Hagos dkk., 2017). Kelarutan minyak essensial kulit batang akway di dalam alkohol $80 \%$ adalah $1: 2$, yaitu satu bagian minyak essensial kulit batang akway larut sempurna pada dua bagian alkohol $80 \%$. Hasil tersebut menunjukkan bahwa konsentrasi tertinggi minyak atsiri kulit batang akway bila dilarutkan dalam alkohol $80 \%$ adalah 33,33\%.

Kelarutan minyak essensial kulit batang akway lebih rendah dibandingkan minyak essensial daun Asteromyrtus brasii, daun Cinammomum burmanii dan rimpang Zingiber officinale yaitu sebesar 1:1 atau konsentrasi minyak essensial tertinggi sebesar 50\% (Widiyanto dan Siarudin, 2014; Nugraheni dkk., 2016; Rialita dkk., 2015). Namun demikian kelarutan minyak essensial kulit batang akway lebih tinggi dibandingkan dengan minyak essensial daun Cupressus benthamii, yaitu 1 : 5 (Wibowo dan Komarayati, 2015). Menurut Hagos dkk. (2017), konsentrasi senyawa terpen teroksigenasi yang tinggi dalam minyak essensial menyebabkan kelarutan minyak essensial dalam alkohol meningkat, sedangkan konsentrasi terpen hidrokarbon yang tinggi menyebabkan kelarutan dalam alkohol menurun.

\section{Kandungan senyawa fitokimia}

Minyak essensial merupakan campuran kompleks dari berbagai senyawa yang berbeda (Butnairu dan Sarac, 2018). Senyawa penyusun utama minyak essensial dapat dibagi dalam dua kelompok senyawa kimia, yaitu terpen dan fenilpropanoid. Terpen dan terpen teroksigenasi merupakan komponen terbesar dalam minyak essensial sedangkan fenilpropanoid merupakan senyawa yang memberikan flavor dan bau khas dari minyak essensial (Moghaddam dan Mehdizadeh, 2017).

Hasil pengujian kandungan senyawa fitokimia minyak essensial kulit batang akway menunjukkan bahwa minyak essensial kulit batang akway mengandung terpenoid, flavonoid, alkaloid dan saponin (Tabel 2.). Kelompok senyawa fitokimia tersebut merupakan kelompok senyawa yang memiliki bioaktivitas yang luas.

Tabel 2. Kandungan kelompok senyawa fitokimia

\begin{tabular}{cc}
\hline Golongan Senyawa & Hasil Pengujian \\
\hline Terpenoid & +++ \\
Flavonoid & ++ \\
Alkaloid & ++ \\
Saponin & + \\
\hline
\end{tabular}

$\overline{\text { Keterangan : +++ positif kuat, ++ positif, }+}$ positif lemah 
Terpenoid merupakan senyawa hidrokarbon yang berasal dari tumbuhan dengan rumus molekul $\left(\mathrm{C}_{5} \mathrm{H}_{8}\right)_{\mathrm{n}}$ termasuk turunannya, yaitu terpen teroksigenasi, terhidrogenasi dan terdehidrogenasi (Yadav dkk., 2014). Senyawa golongan terpen merupakan senyawa penyusun utama dalam minyak essensial kulit batang akway. Cepeda dkk., (2011 $1^{\mathrm{b}}$, melaporkan bahwa minyak essensial kulit batang akway mengandung senyawa terpen sebesar $80,49 \%$ yang terdiri dari senyawa monoterpen dan sesquiterpen. Senyawa terpenoid digunakan sebagai flavor dan fragrans pada pangan dan kosmetik. Senyawa terpenoid juga memiliki bioaktivitas sebagai antikanker, antimalaria, diuretik dan antimikroba (Saxena dkk., 2013).

Senyawa flavonoid merupakan senyawa polifenol dalam tumbuhan yang terdapat dalam bentuk aglikon dan glukosida serta turunan termetilasi (Saxena dkk., 2013). Kelompok senyawa flavonoid terdiri dari flavon, isoflavon, flavonoid, flavonol, flavonon, flavan, anthosianin, proanthosianidin (Altemimi dkk., 2017). Kelompok senyawa flavonoid memiliki aktivitas biologi dan farmakologi yang luas seperti antimikroba, sitotoksisitas, anti-inflamasi dan anti-tumor (Saxena dkk., 2013).

Senyawa alkaloid merupakan kelompok senyawa yang memiliki struktur yang mengandung atom nitrogen heterosiklik (Kennedy dan Wightman, 2011). Cincin heterosiklik dari alkaloid terdiri dari pirolidin, piridin, pirolidin-piridin, piridin-piperidin dan quinolin. Senyawa alkaloid memiliki bioaktivitas sebagai antibakteri, antifungal, antihipertensi, antiarhitmik, antimalaria dan antikanker (Cushnie dkk., 2014; Saxena dkk., 2013).

Saponin merupakan struktur glicosida amphifatik kompleks dari steroid dan triterpenoid yang disintesis secara luas oleh tumbuhan (Faizal dan Geelen, 2013). Saponin bersifat antimikroba, anti fungal, antivirus, immunostimulan, hipoglikemik, hipokolesterolaemik dan antikarsinogenik (Desai dkk., 2009).

\section{Aktivitas antibakteri}

Pengujian antibakteri minyak essensial kulit batang akway dilakukan pada konsentrasi $0-10 \%(\mathrm{v} / \mathrm{v})$ menggunakan medium sintetik nutrient agar. Pengujian ini bertujuan untuk mengetahui potensi antibakteri minyak essensial kulit batang akway terhadap pertumbuhan beberapa bakteri patogen. Hasil pengujian menunjukkan bahwa minyak essensial kulit batang akway dapat menghambat pertumbuhan bakteri patogen $B$. cereus, $P$. aeruginosa, $S$. aureus dan $E$. coli masing-masing dengan diameter zona hambat sebesar 9,43-13,32 mm, 11,43-21,22 mm, $13,31-16,54 \mathrm{~mm}$ dan 11,29-20,43 $\mathrm{mm}$ (Gambar 1.).

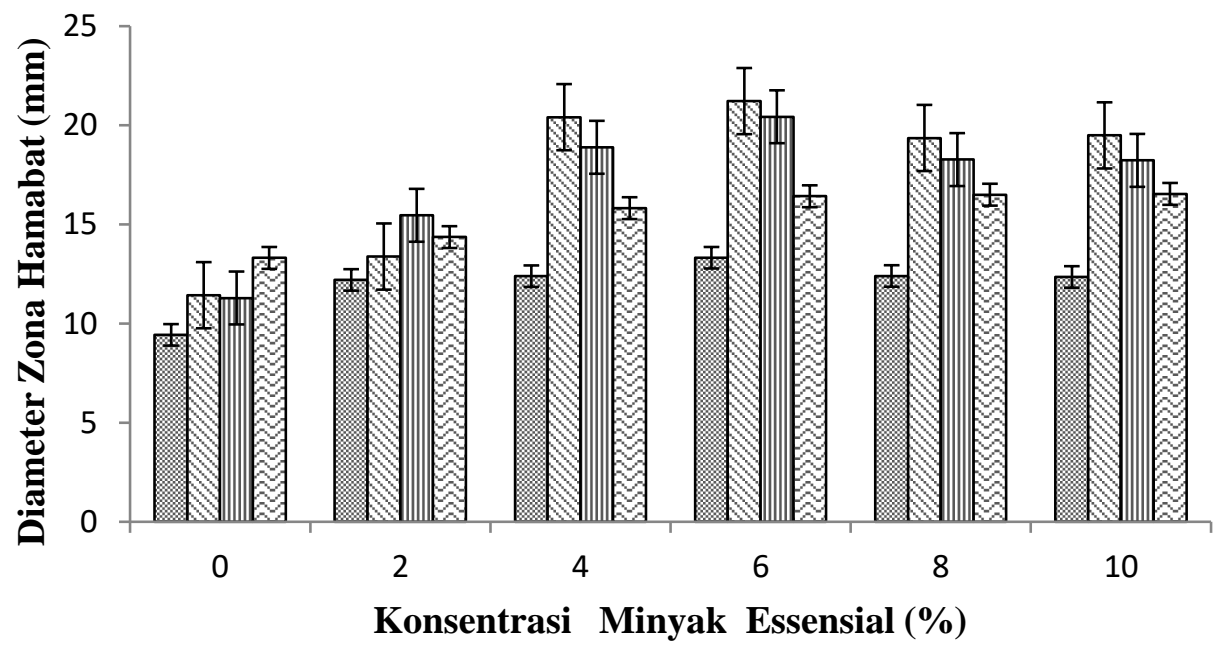

B. cereus $₫ \mathrm{P}$. aeruginosa $\mathrm{mS}$. aureus $\mathrm{QE}$. coli

Gambar 1. Aktivitas antibakteri minyak essensial kulit batang akway 
Penghambatan minyak essensial kulit batang akway terhadap pertumbuhan bakteri patogen cenderung meningkat dengan meningkatnya konsentrasi sampai konsentrasi $6 \%(\mathrm{v} / \mathrm{v})$. Peningkatan konsentrasi dari $6 \%$ menjadi $10 \%$ cenderung menyebabkan terjadinya penurunan diameter zona hambat terhadap pertumbuahan bakteri. Penghambatan minyak essensial kulit batang akway optimum pada konsentrasi 6\%. Menurut Seow dkk. (2014), faktor-faktor yang berpengaruh terhadap antibakteri minyak atsiri diantaranya adalah konsentrasi dan kelarutan minyak essensial. Semakin tinggi konsentrasi minyak essensial menyebabkan semakin besar diameter zona penghambatan terhadap pertumbuhan bakteri. Disamping itu juga faktor kelarutan minyak essensial dalam medium merupakan faktor yang sangat berpengaruh terhadap diameter zona penghambatan dalam medium. Diameter zona penghambatan bergantung pada laju difusi (Davidson and Parish (1989). Minyak essensial memiliki kelarutan yang rendah dalam air (Saranraj dan Devi, 2017). Peningkatan konsentrasi minyak essensial menyebabkan senyawa-senyawa nonpolar semakin meningkat sehingga menurunkan laju diffusi senyawa tersebut dalam medium agar yang bersifat polar. Hal ini menyebabkan pada konsentrasi minyak essensial kulit kayu akway yang tinggi (8-10\%) cenderung tidak meningkatkan diameter zona hambatnya.

Kemampuan minyak essensial kulit batang akway menghambat pertumbuhan bakteri disebabkan oleh komponen antibakteri yang ada dalam minyak essensial kulit batang akway. Minyak essensial kulit batang akway mengandung senyawa terpenoid, saponin, flavonoid dan alkaloid. Senyawa-senyawa tersebut dilaporkan memiliki bioaktivitas sebagai antibakteri (Saxena dkk., 2013; Cushnie dkk., 2014; Barbosa, 2014).

\section{Konsentrasi hambat tumbuh minimum (KHTM)}

KHTM minyak essensial kulit batang akway adalah konsentrasi terendah minyak essensial kulit batang akway yang dapat menghambat pertumbuhan bakteri dalam suatu medium. KHTM minyak essensial kulit batang akway terhadap pertumbuhan bakteri patogen E.coli, B. cereus, P.aeruginosa dan S. aureus bervariasi antara 2,7-5,0 $\mathrm{mg} / \mathrm{ml}$ (Tabel 3.).
Tabel 3. KHTM minyak essensial kulit batang akway

\begin{tabular}{lc}
\hline Jenis Bakteri & KHTM $(\mathbf{m g} / \mathbf{m l})$ \\
\hline B. cereus & 2,7 \\
P. aeruginosa & 5,0 \\
S. aureus & 3,7 \\
E.coli & 4,9 \\
\hline
\end{tabular}

Nilai KHTM minyak essensial kulit batang akway lebih tinggi dibandingkan nilai KHTM minyak essensial kulit batang Cinammomum zeylanicum dan Pinus elliottii, yang masing-masing sebesar $0,5-2,3 \mathrm{mg} / \mathrm{ml}$ dan $0,03-0,10 \mathrm{mg} / \mathrm{ml}$ (Utchariyakiat dkk, 2016; Leandro dkk., 2014) dan lebih kecil dibandingkan minyak essensial daun cengkeh (Syzygium aromaticum) dan minyak essensial sereh (Cymbopogon nardus) yang masingmasing adalah 9-18 $\mathrm{mg} / \mathrm{ml}$ dan 4,5-18 $\mathrm{mg} / \mathrm{ml}$ (Utchariyakiat dkk., 2016). Hasil tersebut menunjukkan bahwa kemampuan antibakteri minyak essensial kulit batang akway lebih kuat dibandingkan minyak essensial daun cengkeh dan sereh.

Tabel 3 juga menunjukkan bahwa konsentrasi terendah minyak essensial kulit batang akway yang dibutuhkan menghambat pertumbuhan bakteri E. coli dan $P$. aeruginosa sebesar 4,9-5,0 $\mathrm{mg} / \mathrm{ml}$ sedangkan untuk bakteri B. cereus dan $S$ aureus sebesar 2,7-3,7 mg/ml. Hasil tersebut menunjukkan bahwa jenis bakteri Gram negatif lebih tahan terhadap minyak essensial kulit batang akway dibandingkan dengan bakteri Gram positif.

Ketahanan bakteri Gram negatif $E$. coli dan $P$. aeruginosa terhadap minyak essensial kulit batang akway disebabkan perbedaan struktur sel bakteri Gram negatif dan bakteri Gram positif. Menurut Nazzaro dkk. (2013), bahwa bakteri Gram negatif lebih tahan terhadap minyak essensial karena lapisan dinding sel bakteri gram negatif memiliki lapisan peptidoglikan yang lebih tipis, namun memiliki lapisan membran terluar (outer membrane) yang mengandung lipopolisakarida (LPS) yang menghalangi masuknya senyawa yang bersifat hidrofobik. Sedangkan Bakteri Gram positif memiliki komposisi lapisan peptidoglikan yang lebih tebal, yaitu sebesar 90-95\% dari lapisan dinding sel, sehingga lapisan ini mudah dilewati oleh senyawasenyawa minyak atsiri yang bersifat hidrofobik. 


\section{KESIMPULAN}

Minyak essensial kulit batang akway memiliki sifat fisik warna jernih kekuningan, kelarutan dalam alkohol $80 \%$ sebesar $1: 1$, dan indeks refraktif 1,4942 . Kandungan minyak essensial dalam kulit batang akway sebesar $0,37 \%$ yang tersusun dari senyawa golongan terpenoid dengan komposisi terbesar, kemudian flavonoid dan alkaloid serta saponin dengan komposisi yang paling kecil. Minyak essensial kulit batang akway dapat menghambat pertumbuhan bakteri patogen $B$. cereus, $E$. coli, $S$. aureus dan $P$. aeruginosa dengan konsentrasi hambat tumbuh minimum sebesar 2,7-5,0 mg/ml. Minyak essensial kulit batang akway berpotensi sebagai sumber antibakteri alami.

\section{DAFTAR PUSTAKA}

Abdelwahab, S.I., Mariod, A.A., Tahal, M.M.E., Zaman, F.Q., Abdelmageed, A.H.A., \& Khamis, S., et al. (2017). Chemical composition and antioxidant properties of the essential oil of Cinnamomum altissimum kosterm. (Lauraceae). Arabian Journal of Chemistry, 10: 131-135.

Al-fekaiki, D. F., Niamah, A. K., and AlSahlany, S. T. G. (2017). Extraction and identification of essential oil from Cinammomum zeylanicum barks and study the antibacterial activity. Journal of Microbiology, Biotechnology and Food Sciences, 7(3): 312-316.

Altemimi, A., Lakhssassi, N., Baharlouei, A., Watson, D.G., \& Lightfoot, D.A. (2017). Phytochemicals: Extraction, Isolation, and Identification of Bioactive Compounds from Plant Extracts. Plants, 6 (42): 1-23.

Badasa, S., Bufebo, T., Derbe, T., and Mariam, Y. W. (2014). Physicochemical analysis of essential oil of Lantana camara L. leaf of Mekelle, Ethiopia. World Journal of Pharmacy and Pharmaceutical Sciences, 3(10): 1349-1357.

Barkatullah., Ibrar, M., Rauf, A., \& Rahman, I. U. (2012). Physicochemical characterization of essential and fixed oils of Skimmia laureola and Zanthoxylum armatum. Middle-East
Journal of Medicinal Plants Research, 1(3): 51-58.

Bloomfield, S. (1991). Methods for assesing antimicrobial activity. In S. P. Denyer, H. B. Hugo, editor. Mechanism of action of chemical biocides their study and exploitation (pp.1-22). London: Scientific Publication.

Butnariu, M., \& Sarac, I. (2018). Essential oils from plants. Journal of Biotechnology and Biomedical Science, 1(4): 35-43.

Cabarkapa, I.S., Duragic, O.M., \& Kostadinovic, L.M. (2016). Essential Oils: Mode of Antimicrobial Activity and Potential Application in Food Systems. Agro FOOD Industry Hi Tech, 27(3):61-64.

Cepeda, G.N., Santoso, B.B., Lisangan, M.M. dan Silamba, I. 2011 ${ }^{\mathrm{a}}$. Komposisi kimia minyak atsiri daun akway. Makara Sains 15(1): 63-66.

Cepeda, G.N., Santoso, B.B., Lisangan, M.M. dan Silamba, I. 2011 $1^{\text {b }}$ Komposisi kimia minyak atsiri kulit kayu akway (Drimys piperita Hook f.). Bionatura 13(2) : 118124.

Cushnie, T.P.T., Cushnieb, B., \& Lambc, A.J. (2014). Alkaloids: An overview of their antibacterial, antibiotic-enhancing and antivirulence activities. International Journal of Antimicrobial Agents, 44: 377-386.

Damayanti, R., Fahmi, C. N., \& Efendi, R. (2015). Physical properties of essential oil of leave pala (Myristica fragrans Houtt) of South Aceh. Jurnal Biologi Lingkungan, Industri, Kesehatan, 1(2): 76-80.

Davidson, P. M., and Parish, M. E. 1989. Methods for testing the efficacy of food antimicrobial. Food Technology, 148155

Desai, S.D., Desaib, D.G., \& Kaurc, H. (2009). Saponins and their Biological Activities. Pharma Times, 41(3): 13-16.

Duarte, M.C.T., Duarte, R.M.T., Rodrigues, R.A.F., \& Rodrigues, M.V.N. (2018). Essential Oils and Their Characteristics. In S.M.B. Hashemi, A.M. Khaneghah, A. S. Sant'Ana, Editor. Essential Oils in Food Processing: Chemistry, Safety and Applications (pp. 1-19). USA: John Wiley \& Sons Ltd.

Faizal, A., \& Geelen, D. (2013). Saponins and their role in biological processes in 
plants. Phytochemistry Review, 12:877893.

Hagos, Z., Mulugeta, A., Gopalakrishnan, V. K., Krishna, C. K., \& Nagaraju, B. (2017). Chemical composition and physicochemical properties of essential oil from Myrtus communis. International Journal of Pharmaceutical and Clinical Research, 9(6): 439-443.

Harborne, J. B. (1996). Metode Fitokimia. Bandung: Penerbit ITB.

Huong, B. V., Anh, L. D. N., \& Dat, N. V. (2018). Stem bark essential oil composition of Schefflera quangtriensis C. B. Shang. Chemistry Research Journal, 3(5):69-72.

Kennedy, D.O., \& Wightman, E.I. (2011). Herbal Extracts and Phytochemicals: Plant Secondary Metabolites and the Enhancement of Human Brain Function. Advances in Nutrition, 2: 32-50.

Koohyar, F. (2013). Refractive Index and Its Applications. Journal of Thermodynamics \& Catalysis, 4(2): 117.

Leandro, L.F., Cardoso, M.J.O., Silva, S.D.C., Souza, M.G.M., Veneziani, R.C.S., \& Ambrosio, S.R. (2014). Antibacterial activity of Pinus elliottii and its major compound, dehydroabietic acid, against multidrug-resistant strains. Journal of Medical Microbiology, 63: 1649-1653.

López, E.I.C., Balcázar, M.F.H., Mendoza, J.M.R., Ortiz, A.D.R., Melo, M.T.O., \& Parrales, R.S., et al. (2017). Antimicrobial Activity of Essential Oil of Zingiber officinale Roscoe (Zingiberaceae). American Journal of Plant Sciences, 8: 1511-1524.

Majumder, M., Sharma, H. K., Zaman, K., \& Lyngdoh, W. (2014). Evaluation of physico-chemical properties and antibacterial activity of the essential oil obtained from the fruit of Zanthoxylum acanthopodium DC. Collected from Meghalaya India. International Journal of Pharmacy and Pharmaceutical Sciences, 6(5):543-546.

Mansour Amin, Enayat Kalantar, Neda Mohammad-Saeid, and Behzad Ahsan. (2010). Antibacterial effect and physicochemical properties of essential oil of Zataria multiflora Boiss. Asian Pacific Journal of Tropical Medicine, 3(6):439-442.
Marzuki, I., Joefrie, B., Aziz, S. A., Agusta, H., \& Surahman, M. (2014). Physicochemical characterization of Maluku nutmeg oil. International Journal of Science and Engineering, 7(1):61-64.

Moghaddam M., \& Mehdizadeh, L. (2017). Chemistry of Essential Oils and Factors Influencing Their Constituents. In A. M. Grumezescu, A. M. Holban, editor. Handbook of Food Bioengineering Vol. 3 (pp. 379-419). London: Academic Press.

Nazzaro, F., Fratianni, F., De Martino, L., Coppola, R., \& De Feo, V. (2013). Effect of Essential Oils on Pathogenic Bacteria. Pharmaceuticals, 6: 14511474.

Nugraheni, K. S., Khasanah, L. U., Utami1, R., \& Ananditho, B. K. (2016). Pengaruh perlakuan pendahuluan dan variasi metode destilasi terhadap karakteristik mutu minyak atsiri daun kayu manis (C. Burmanii). Jurnal Teknologi Hasil Pertanian, 9 (2): 51-64.

Ospina, J. D., Tovar, C. D. G., , Flores, J. C. M., \& Orozco, M. S. S. (2016). Relationship between refractive index and thymol concentration in essential oils of Lippia origanoides Kunth. Chilean Journal of Agricultural \& Animal Sciences, 32(2): 127-133.

Perricone, M., Arace, E., Corbo, M.R., Sinigaglia, M., \& Bevilacqua, A. (2015). Bioactivity of essential oils: a review on their interaction with food components. Frontiers in Microbiology, 6: 1-7.

Rassem, H. H. A., Nour, A. H., \& Yunus, R. M. (2016). Techniques for extraction of essential oils from plants: A review. Australian Journal of Basic and Applied Sciences, 10(16): 117-127

Rialita, T., Rahayu, W. P., Nuraida, L., \& Nurtama, B. (2015). Aktivitas antimikroba minyak esensial jahe merah (Zingiber officinale var. Rubrum) dan lengkuas merah (Alpinia purpurata $\mathrm{K}$. Schum) terhadap bakteri patogen dan perusak pangan. Agritech, 35(1): 43-52.

Santos, T. G., Dognini, J., Begnini, I. M., Rebelo,. R. A., Verdi, M., De Gasper, A. L., \& Dalmarcod, E. M. (2013). Chemical characterization of essential oils from Drimys angustifolia Miers (Winteraceae) and antibacterial activity of their major compounds. Journal of 
Brazillian Chemistry Society, 24(1): 164-170.

Saranraj, P., and Devi, V.D. (2012). Essential Oil and Its Antibacterial Properties - A Review. Life Science Archives (LSA), 3(2): $994-1011$.

Saxena, M., Saxena, J., Nema, R., Singh, D., and Gupta, A. (2013). Phytochemistry of Medicinal Plants. Journal of Pharmacognosy and Phytochemistry, 1(6):168-182.

Seow, Y.X., Yeo, C.R., Chung, H.L., and Yuk, H-G. 2014. Plant essential oils as active antimicrobial agents. Critical Reviews in Food Science and Nutrition 54:625-644.

Shabbir, M. K., Nadeem, R., Mukhtar, H., Anwar, F., and Mumtaz, M. W. (2009). Physico-chemical analysis and determination of various chemical constituents of essential oil in Rosa centifolia. Pakistan Journal of Botany, 41(2): 615-620.

Tiwari, P., Kumar, B., Kaur, M., Kaur, G., and Kaur, H. (2011). Phytochemical Screening and Extraction: A Review. Internationale Pharmaceutica Sciencia, 1(1): 98-106.
Turek, C., and Stintzing, F.C. (2013). Stability of Essential Oils: A Review. Comprehensive Reviews in Food Science and Food Safety, 12:40-53.

Utchariyakiat, I., Surassmo, S., Jaturanpinyo, M., Khuntayaporn, P., and Chomnawang, M.T. (2016). Efficacy of cinnamon bark oil and cinnamaldehyde on anti-multidrug resistant Pseudomonas aeruginosa and the synergistic effects in combination with other antimicrobial agents. BMC Complementary and Alternative Medicine, 16:158.

Wibowo, S., and Komarayati, S. (2015). Sifat fisiko kimia minyak cupresus (Cupressus benthamii) asal Aek Nauli, Parapat Sumatera Utara. Jurnal Penelitian Hasil Hutan, 33(2): 93-103.

Widiyanto, A., and Siarudin, M. (2014). Sifat fisikokimia minyak kayu putih jenis Asteromyrtus brasii. Jurnal Penelitian Hasil Hutan, 32(4): 243-252.

Yadav, N., Yadav, R., and Goyal, A. (2014). Chemistry of Terpenoids. International Journal of Pharmaceutical Sciences Review and Research, 27(2): 272-278. 